\title{
Kreatifitas Survivor Skizofrenia dalam Upaya Kesembuhan Di Kecamatan Kersamanah Kabupaten Garut
}

\author{
Creativity Survivor Schizofrenia in Recovery Process in Kersamanah Garut
}

\section{Lina Rahmawati}

\author{
Akper Saifuddin Zuhri Indramayu \\ e-mail: *linarahmawati2409@gmail.com, aksari_zuhri@yahoo.com
}

\begin{abstract}
Abstrak
Banyak upaya kesembuhan dilakukan oleh survivor skizofrenia, akan tetapi perlu upaya kreatifitas survivor skizofrenia agar mereka tetap survive dan menjalani hidup dengan harapan akan terlepas dari penyakit gangguan jiwa. Penelitian ini bertujuan mengungkap secara mendalam tentang kreatifitas survivor skizofrenia dalam upaya kesembuhan. Jenis penelitian yang digunakan adalah kualitatif dengan pendekatan fenomenologi. Data diperoleh melalui wawancara mendalam pada 7 survivor skizofrenia yang tidak kambuh sekurang-kurangnya 2 tahun, mampu memenuhi kebutuhan sendiri, akan tetapi masih mengupayakan kegiatan lain untuk menambah penghasilan, mampu melakukan ibadah rutin, akan tetapi melakukan kegiatan ibadah lainnya, mandiri melakukan pemenuhan kebutuhan sehari-hari seperti mandi, makan, membersihkan rumah dll, akan tetapi menambah aktifitas lainnya demi kesembuhan, mampu bersosialisasi dan kooperatif. Data hasil wawancara di trankrip verbatim dan dianalisa data melali metode collaizi. Hasil penelitian diperoleh tema 6 tema yaitu membuat kerajinan tangan, makanan dan kue, berkebun dan berternak, bekerja dan berjualan, mengurus anak dan membantu pekerjaan rumah, berbincang-bincang dengan orang lain, dan melakukan atifitas didalam dan diluar rumah. Disimpulkan bahwa kreatifitas survivor skizofrenia merupakan upaya lain yang dilakukan selain recovery karena mereka selain berjuang melawan penyakitnya, mereka terus berupaya melakukan upaya-upaya kesembuhan lainnya sampai sekarang menjadi individu yang sudah sembuh.

Kata kunci: Kualitatif, Kreatifitas Survivor Skizofrenia, Upaya Kesembuhan.
\end{abstract}

\footnotetext{
Abstrack

The workers should consume foods that are balanced and maximize resting time. Extracts

Many recovery efforts were carried out by schizophrenic survivors, but the efforts of the schizophrenic survivors need to be creative so that they can survive and live their lives in the hope of being released from mental illness. This study aims to reveal in depth about the creativity of schizophrenic survivors in the recovery effort. The type of research used is qualitative with a phenomenological approach. Data obtained through in-depth interviews with 7 schizophrenic survivors who did not relapse at least 2 years, were able to meet their
}

own needs, but still sought other activities to supplement income, be able to perform routine worship, but do other worship activities, independently fulfill the needs of a day days such as bathing, eating, cleaning the house etc., but adding other activities for healing, being able to socialize and cooperate. Interview data in the verbatim transcripts and analyzed data through the collaizi method. The results of the study were the theme of 6 themes, namely making crafts, food and cakes, gardening and raising livestock, working and selling, taking care of children and helping with homework, chatting with other people, and doing activities inside and outside the home. It was concluded that the creativity of survivors of schizophrenia was another effort that was carried out in addition to recovery because in addition to struggling against the disease, they continued to strive to make other healing efforts until now being individuals who had recovered.

Keywords: Qualitative, Schizophrenic Survivor Creativity, Efforts to Heal.

\section{Pendahuluan}

Kontekstual penelitian ini berdasarkan hasil penelitian sebelumnya yang dilakukan Rahmawati (2015) mengenap pengalaman hidup survivor skizofrenia dalam proses recovery di Kersamanah Kabupaten Garut diperoleh 7 tema penelitian yaitu motivasi kesembuhan berasal dari diri sendiri dan orang lain, kemampuan mengendalikan fikiran dan emosi, kemampuan mengontrol halusinasi, kemampuan mencari solusi permasalahan sehari-hari, kemampuan menghadapi stigma masyarakat, mencari pertolongan Allah untuk keyakinan, dan harapan terhadap pemerintah. ${ }^{1}$

Hasil penelitian sebelumnya dirasa kurang, sebetulnya masih banyak yang dilakukan survivor dalam upaya kesembuhannya. Upaya kesembuhan yang sudah dilakukan pasien adalah hal yang utama dalam proses recovery, akan tetapi hal lainnya dilakukan survivor 
dalam upaya kesembuhannya atau dikenal dengan istilah kreatifitas. Perjalanan individu dalam proses pemulihan tidaklah mudah, diperlukan segala upaya selain upaya yang biasa dilakukan.

Dalam sebuah grup media sosial KPSI (Komunitas Peduli Skizofrenia Indonesia) Simpul Bandung seorang anggota akun tersebut meminta informasi mengenai pekerjaan atau bantuan untuk wirausaha bagi penderita gangguan jiwa. Dari pernyataan tersebut jelas bahwa Survivor skizofrenia sangat membutuhkan pekerjaan untuk memenuhi kebutuhannya sehari-hari sehingga sangat dibutuhkan kreatifitas dalam melakukan aktifitas yang dapat memenuhi kebutuhan sehari-harinya selain aktifitas rutin.

Penelitian yang dilakukan oleh Karmilawati (2011) mengenai hubungan keaktifan terapi okupasi dengan tingkat kreatifitas pasien skizofrebia di Surakarta. Disimpulkan bahwa salah satu factor yang menyebabkan kreatifitas pasien skizofrenia adalah terapi okupasi. Kreatifitas dalam penelitian tersebut dipicu dari luar yaitu terapi okupasi yang dilakukan perawat, akan tetapi bagaimana kreatifitas yang dilakukan sendiri oleh survivor skizofrenia, hal tersebut penting untuk diketahui karena kreatifitas timbulnya bias dari dalam diri maupun dari luar. ${ }^{2}$

Hasil wawancara pada Ny. E mengalami gangguan jiwa 10 tahun lalu, saat ini sudah sembuh walaupun keterbatasan. Ny. E menceritakan awal sakit setelah menjadi TKW (Tenaga Kerja Wanita) di Saudi Arabia selama 1 bulan, mulai mendengar sesuatu semakin parah dan menggelandang. Suatu ketika Ny. E bertekad untuk sembuh demi anak angkatnya dan suami sehingga melakukan segala upaya demi kesembuhannya. Ny. E melakukan tugasnya sebagai ibu rumah tangga dengan baik, selain itu Ny. E melaksanakan aktifitas selain kesehariannya seperti berjualan, menjadi pembatu rumah tangga di rumah saudara, membantu kader jiwa, membuat hiasan/mute, dll.
Fenomena yang terjadi pada pasien gangguan jiwa mengalami kekambuhan salah satunya karena tidak kreatif dalam melakukan aktifitasnya sehari-hari. Pasien banyak diam, bosan dan tidak melakukan aktifitas apapun.

Hasil penelitian Norsyehan, Lestari \& Mulyani (2015) mengungkapkan bahwa kreatifitas pasien skizofrenia dapat diungkapkan melalui lukisan. ${ }^{3}$ lukisan dapat menjadi bentuk komunikasi, melatih perhatian dan keterampilan sehingga meningkatkan fungsi kognitif. Lebih lanjut Riyadi \& Purwanto (2009) mengungkapkan terapi okupasi pada pasien skizofrenia meningkatkan kemandirian dan kreatifitas. ${ }^{4}$

Hanna Al Fikih Survivor Skizofrenia dalam sebuah seminar di RSJ Provinsi Jawa Barat Tahun 2014 mengungkapkan bahwa dirinya melukis dan menghasilkan uang dari lukisannya tersebut.Penelitian tersebut dilakukan oleh remaja atau orang yang memiliki keahlian melukis sebelum menderita gangguan jiwa sudah, memiliki lingkungan seniman sehingga mudah mengembangkan bakat dan disalurkan, sementara penderita gangguan jiwa yang ada di Kersamanah Kabupaten Garut terhalang oleh sulitnya akses ke kota, daerah masih pegunungan dan mata pencaharian pertanian, maka kreatifitas mereka disesuaikan dengan letak geografis, budaya maupun kebiasaan masyarakat setempat dan yang pasti menghasilkan pendapatan bagi pasien tersebut.

Kreatifitas merupakan proses yang melibatkan imajinasi, ide dan gagasan asli dari pemikiran individu. Kreatifitas sering diartikan kegilaan, berbeda dengan pemikiran pada umumnya, dan sesuatu yang berbeda. Setiap manusia merupakan individu yang kreaif. Manusia dapat mencapai hal-hal yang besar apabika pikirannya dilatih dengan baik. Kegilaan dalam ilmu sastra sering diartikan seni (Mainkar, Maya. 2014). ${ }^{5}$

Banyak tokoh seni yang mengalami gangguan jiwa memiliki latar belakang kehidupan yang keras, penolakan sosial, 
kehilangan orang tua. Ini bukan berarti bahwa gangguan jiwa merupakan faktor penentu keberhasilannya. Kreatifitas dapat diwujudkan dalam berbagai cara, antara lain dalam proses belajar, kegiatan sehari-hari maupun kreatifitas seni professional. ${ }^{6}$

Manfaat kreatifitas bagi kesehatan jiwa menyalurkan ekspresi, menyalurkan perasaan yang dapat menyebabkan ketegangan, mengatasi kecewa, khawatir, takut dll. Selain itu manfatat kreatifitas dapat membantu mengatasi masalah, mengekspresikan berbedabeda, memberikan kepuasan seseorang dan mempengaruhi perkembangan sosial emosi pasien.

Penyembuhan gangguan mental melalui kreatifitas salah satunya melalui melukis. Melukis merupakan bentuk seni rupa yang dapat memberikan gambaran mengenai perubahan bagi kesehatan mental penderita. Bahwa seni rupa membawa perubahan kesehatan mental penderita. Seni merupakan salah satu dari kreatifitas pasien gangguan jiwa yang berhubungan dengan psikologi. Kreatifitas melibatkan emosi, pikiran yang mengendap dan terinternalisasi dan tersalurkan

Pentingnya mengembangkan kreatifitas pasien jiwa oleh perawat adalah agar perawat dapat mengembangkan kreatifitas pasien, melakukan pemberdayaan pasien skizofrenia baik di Rumah Sakit maupun Masyarakat sehingga Survivor dapat produktif dan memenuhi kebutuhannya sendiri walaupun dalam keterbatasan.

\section{Metode Penelitian}

Desain penelitian adalah deskriptif kualitatif untuk menggali dan memahami makna yang terjadi pada survivor skizofrenia. ${ }^{7}$ Fenomenologi merupakan suatu pendekatan yang digunakan untuk mempelajari fenomena pada manusia. ${ }^{8}$ Tujuan penelitian fenomenologi yaitu menginterpretasikan, menganalisis dan mendeskripsikan data secara mendalam, lengkap dan terstruktur untuk memperoleh intisari (esense) dari pengalaman survivor skizofrenia.

Perhitungan partisipan dalam penelitian kualitatif tidak berdasarkan statistic, akan tetapi dipilih melalui teknik purposive sampling. Populasi dalam penelitian ini berjumlah 7 survivor yang berada di wilayah Puskesmas Kersamanah Kabupaten Garut. Wawancara dilakukan secara mendalam dan dihentikan ketika peneliti mencapai saturasi data. Kriteria sampel antara lain survivor yang sebelumnya didiagnosa skizofrenia, akan tetapi telah dinyatakan sembuh oleh dokter Puskesmas yang berkoordinasi dengan Spesialis Jiwa sekurang-kurangnya 2 tahun tidak dirawat di Rumah Sakit Jiwa, mampu mengontrol halusinasi, waham dan gejala lain. ${ }^{9}$

Selain itu survivor tidak mengalami gangguan kognitif, tidak memiliki riwayat penggunaan NAPZA, memiliki insight baik, tidak retardasi mental, dan kooperatif.

Kriteria survivor yang kreatif antara lain

1. Sudah beribadah, akan tetapi melakukan kegiatan lain selain rutinitas ibadah

2. Sudah mampu memenuhi kebutuhan sendiri, walaupun dalam keterbatasan, akan tetapi mencari kegiatan lain untuk menambah penghasilan

3. Sudah mampu melaksanakan aktifitas pemenuhan kebutuhan sehari-hari seperti : mandi, makan, bersih-bersih rumah, akan tetapi tetap melakukan kegiatan lain untuk menambah aktifitasnya

\section{Hasil \\ Karakteristik Responden \\ Survivor 1}

Ny. S berusia 38 tahun, alamat Desa Kersamanah, ibu rumah tangga, agama Islam, suku Sunda, dan sudah menikah, memiliki insight baik, dapat bersosialisasi dengan tetangga maupun masyarakat dan hidup mandiri bersama suami memenuhi kebutuhan 
sehari-hari. Pertama mengalami gangguan jiwa ketika menjadi tenaga kerja wanita (TKW) di Kuwait tahun 2007 dengan kondisi mendengar dan melihat sesuatu yang tidak nyata seperti melihat burung majikan dapat berbicara dan menyuruhnya segera pulang ke Indonesia, mendengar tetangganya menelepon, kabur dari rumah majikan dengan tidak mengenakan pakaian dan akhirnya dipulangkan ke Indonesia. Ny. S keluyuran dan tidak memakai pakaian ketika di Indonesia, merasa ingin mati, dan melakukan percobaan bunuh diri.

Ny. S dibawa ke klinik Nurilahhi Bandung sebanyak 2 kali di tahun 2008, kemudian pernah dirawat di RSUD Slamet Garut 1 kali. Ny. S sembuh pada tahun 2013, suatu waktu perasaan Ny. S tiba-tiba tenang dan sejuk, Ny. $\mathrm{S}$ bertekad ingin membahagiakan suaminya yang selama ini setia mendampinginya selama mengalami gangguan jiwa.

Titik balik Ny. S sembuh karena suaminya. Ny. S mengungkapkan suaminya bagaikan malaikat, meskipun selama 16 tahun menikah tidak memiliki keturunan, akan tetapi suaminya sangat mendukung dan selalu mendampingi ketika masih kambuh harus bolak-balik berobat ke klinik maupun rumah sakit jiwa (RSJ). Ny. S tidak ingin pengorbanan suaminya sia-sia sehingga memiliki tekad dan motivasi yang kuat untuk sembuh.

\section{Survivor 2}

Tn. A usia 55 tahun, pedagang, agama Islam, suku Sunda, duda, alamat Desa Cioray. Tn. A menerima dirinya pernah mengalami gangguan jiwa, dapat memenuhi kebutuhannya sendiri, membantu memenuhi kebutuhan anak dan cucunya, dapat bersosialisasi, dan mengikuti kegiatan masyarakat seperti pengajian. Riwayat pertama mengalami gangguan jiwa sejak tahun 1993 ketika itu Tn. A mengamuk di rumahnya dan sering mendengar seseorang memanggil ketika mencangkul di kebun, bicara melantur, dan mudah marah. Tn. A pertama kali dirawat di
RSJ tahun 1993 dan telah 3 kali dirawat di RSJ Cisarua (ketika ditanyakan rentang waktunya lupa) dan terakhir dirawat di RSJ Riau Bandung tahun 2006 dan setelah tahun 2006 tidak pernah kambuh.

Titik balik Tn. A sembuh, yaitu karena anak-anak dan cucunya. Tn. A rela mengorbankan hartanya demi kesembuhannya. Sawah dan kebun sekitar 75 bata dijualnya sepanjang 20 tahun pengobatannya ketika harus bolak-balik RSJ. Tn. A yakin bahwa harta dapat dicari, akan tetapi kesembuhan tidak akan terwujud apabila dirinya tidak mengorbankan hartanya. Tn. A dapat berjuang melawan penyakitnya, walaupun dalam keterbatasan ekonomi dan merasa kesembuhan itu salah satunya juga dikarenakan sedekah yang dilakukannya kepada gelandangan psikotik yang ditemuinya ketika berjualan bandros keliling. Tn. A dapat bersedekah meskipun sebetulnya dirinya berada dalam keterbatasan ekonomi.

\section{Survivor 3}

Ny. U, berusia 33 tahun, ibu rumah tangga, agama Islam, suku Sunda, dan alamat Desa Nanjungjaya. Ny. U menerima dirinya pernah mengalami gangguan jiwa, dapat menjalankan perannya sebagai ibu rumah tangga, membantu suami memenuhi kebutuhan sehari-hari, dapat bersosialisasi, dan mengikuti kegiatan masyarakat seperti pengajian, mengajar di taman pendidikan anak (TPA). Ny. U mengalami ganggguan jiwa sejak SLTP kelas 2, saat itu bapaknya meninggal dan kakaknya juga mengalami gangguan jiwa kronik. $\mathrm{Ny}$. U saat itu merasa tertekan karena selain sekolah juga mengurus kakaknya, mengurus keluarga. Ketika Ny. U SMP kakaknya bunuh diri membakar dirinya dengan minyak tanah dan setelah SMA Ny. U merasa saat itu gejala gangguan jiwa sudah muncul dan diperberat oleh keinginan kuat untuk kuliah sementara keluarga tidak mampu. Ny. U merasa terguncang sampai pikirannya kacau, keluyuran, cepat emosi, mandi di luar rumah, 
memakai baju pendek (biasanya santun berkerudung), melihat hal ghaib seperti jin tinggi besar, melihat orang terbang sampai akhirnya tahun 2001 keluarga membawa Ny. U ke RSJ Cisarua. Ny. U setelah pulang dari RSJ bekerja kembali di Subang beberapa bulan setelahnya dirawat kembali pada tahun yang sama. Ny. U dirawat untuk yang ketiga kalinya di RSJ Riau Bandung tahun 2004.

Ny. U menikah pada tahun 2007 dan setelah 3 bulan melahirkan kambuh kembali dan dibawa ke RSJ, ketika perjalanan menuju RSJ dan bertekad ingin sembuh. Ny. U kemudian dicerai setelah pulang dari RSJ. Ny. U merasa sakit hati, tidak percaya, bertekad ingin sembuh, berpikir hidup saya tidak akan begini saja, dan ingin bekerja supaya dapat terus berobat ke Puskesmas Setelah pulang dari RSJ biasanya melamun dan hanya diam, akan tetapi Ny. U langsung membereskan rumah, mencuci, mengerjakan semua pekerjaan rumah. Ny. U bekerja dan rajin minum obat dari puskesmas dan sampai saat ini gejala yang dahulu dialaminya sudah tidak ada dan sudah 10 bulan ini menikah kembali bersama suaminya terdahulu.

\section{Survivor 4}

Ny. K ibu rumah tangga, agama Islam, alamat Desa Nanjungjaya. Ny. K menyadari dirinya pernah mengalami gangguan jiwa, dapat menjalankan aktivitas rumah tangga, serta dapat bersosialisasi dengan tetangga dan masyarakat. Ny. K mengalami gangguan jiwa sejak 20 tahun yang lalu, pernah di rawat di RSJ selama 3 kali dari kurun waktu 20072009. Ny. K ketika itu merasa tidak sadar yang terjadi pada dirinya, keluyuran dan tidak mengenakan pakaian, mendengar suara-suara, dan mengamuk. Ny. $\mathrm{K}$ mengungkapkan kambuh ditahun 2009 disebabkan oleh beban pikiran ingin segera menyelesaikan pembangunan rumahnya. Setelah dirawat di RSJ tahun 2009 sembuh dan halusinasi yang dialaminya hilang. Semenjak itu Ny. K tidak pernah kambuh, rutin minum obat, dan menjalankan aktivitasnya sebagai ibu rumah tangga. Ny. $\mathrm{K}$ membuka lembaran baru dengan menikah kembali dengan suami keduanya.

Titik balik Ny. K sembuh itu karena anaknya. Ny. $\mathrm{K}$ mengungkapkan dirinya sembuh karena anaknya, bagaimana kelak anaknya apabila masih saja gangguan jiwa seperti dahulu. Lebih lanjut $\mathrm{Ny}$. K mengungkapkan siapa yang mengurus anaknya apabila dirinya kambuh. Dirinya berkeinginan kuat sembuh demi anak-anaknya. Anaknya yang paling besar sekarang sudah SLTP dan menurutnya sudah dewasa, bagaimana perasaan anaknya jika mendapati dirinya mengalami gangguan jiwa kembali.

\section{Survivor 5}

Tn. U berusia 40 tahun, buruh bangunan, agama Islam, suku Sunda, alamat Desa Sukamaju, dan sudah menikah. Tn. U sadar dirinya pernah mengalami gangguan jiwa, bekerja sebagai buruh bangunan untuk memenui kebutuhan keluarga, dan mengikuti pengajian rutin di lingkungannya. Pertama mengalami gangguan jiwa semenjak tahun 2000 tanpa mengetahui penyebabnya secara jelas hanya mengungkapkan gajinya tidak dibayarkan ketika bekerja di Sumatera. Tn. U ketika itu mengalami beban pikiran yang berhubungan dengan pekerjaan, awalnya sabar, berdzikir, dan menyendiri. Tn. U ketika itu melihat bayangan dan mendengar suarasuara, suara-suara tersebut membawanya sampai ke Lampung. Tn. U sekuat tenaga melawan halusinasi tersebut dan selama 8 hari akhirnya sampai ke rumahnya di Garut. Tn. U mengalami mengalami kekambuhan lagi ketika membangun rumahnya, Tn. U mengamuk, mendengar suara-suara yang banyak sekali dan melihat bayangan.

Tn. U tidak pernah dirawat di RSJ dan hanya berobat ke dokter spesialis jiwa di Tasikmalaya, kemudian kambuh dan berobat kembali. Tn. U berpikir harus sembuh karena biaya pengobatan mahal. Tn. U bertekad untuk 
sembuh demi anak dan istrinya, tidak ingin anaknya merasa rendah diri memiliki ayah yang mengalami gangguan jiwa, Tn. U berjuang melawan halusinasinya, selalu beribadah dan mengontrol dirinya agar tidak kambuh. Tn. U ingin membuktikan bahwa meskipun dirinya mengalami gangguan jiwa, akan tetapi tidak kalah dengan orang lain yang tidak mengalami gangguan jiwa.

\section{Survivor 6}

Tn. E usia 46 tahun, wiraswasta, agama Islam, suku Sunda, alamat Desa Bandrek, dan sudah menikah. Tn E menyadari dirinya pernah mengalami ganguan jiwa, bekerja memenuhi kebutuhan keluarganya membuat salon/pengeras suara walaupun dibantu istrinya, dapat bersosialisasi dengan teman, tetangga, dan saudara. Tn. E mengalami gangguan jiwa sekitar tahun 1993 ketika kuliah di Politeknik Bandung, ketika itu Tn. E menjelaskan bahwa karena kuliahnya tidak sesuai dengan keinginan maka tugas-tugas kuliah itu beban baginya dan akhirnya kurang tidur, mendengar suara-suara, bicara kacau, dan keluyuran. Tn. E ketika itu dirawat di RSJ Riau kemudian pulang dan kambuh kembali karena tidak rutin minum obat begitu hingga 3 kali bolak-balik RSJ Riau dalam kurun waktu 10 tahun sampai akhirnya tahun 2004 menikah dan sembuh.

Tn. E semenjak berumah tangga sembuh, Tn. E mengatakan motivasi kesembuhan berasal dari keluarga, Tn. E juga beryukur memiliki istri yang selalu mengingatkannya rutin minum obat karena baginya tidak sembuh jika tidak rutin minum obat. Tn. E terus berjuang melawan pikiran negatif yang selalu mengajaknya untuk keluyuran. Saat ini Tn. E merasa bahagia dapat sembuh, walaupun harus terus menerus minum obat.

\section{Survivor 7}

Tn. A usia 37 tahun, buruh, agama Islam, suku Sunda, alamat Desa Sukamaju, dan seorang duda. Tn. A menyadari dirinya pernah mengalami gangguan jiwa, bekerja membantu bapaknya di sawah, dan dapat bersosialisasi dengan teman, tetangga, saudara, dan masyarakat. Tn. E mengalami gangguan jiwa sekitar tahun 2008, Tn. A menjelaskan bahwa gejalanya muncul akibat beban memikirkan masalah ekonomi, ketika itu dipecat dari pekerjannya, melamun, berhalusinasi, mengamuk dan merusak barang. Tn. A dirawat di Nurilahi Bandung. Tn. A kambuh kembali tahun 2013 karena anaknya meninggal dirawat di RS. Hasan Sadikin. Tn. A mengatakan sembuh sepulang dari Rumah Sakit kemudian mandi, sholat dan ketika itu pikirannya menjadi terang dan timbul semangat ingin bekerja kembali. Tn. A saat ini mengalami luka bakar di tangan kiri yang menyulitkannya untuk bekerja, namun tidak menyurutkan semangatnya untuk bekerja dan beraktivitas. Tn. A memenuhi kebutuhannya bekerja di sawah bapaknya dan apabila kekurangan dibantu oleh orang tuanya. Tn. A dapat berobat sendiri ke puskesmas untuk mengobati tangannya akibat luka bakar.

\section{Pembahasan}

Dari hasil analisis colaizzi, diperoleh 6 tema, yaitu

\section{Membuat kerajinan tangan, makanan dan kue}

Menurut penelitian Nursalim (2016) mengenai pengembangan kreatifitas orang dengan skizofrenia di Panti Hafara bahwa pengembangan kreatifitas membawa dampak positif bagi pasien skizofrenia, mereka menjadi lebih percaya diri akan kemampuan yang dimiliki, menjadi aktif, antusias dan semangat dalam mengikuti kegiatan, serta mengurangi potensi kambuh. Dalam penelitian tersebut target pengembangan kreatifitas pasien yaitu menghasilkan uang hasil karya pasien. ${ }^{10}$ Salah satu upaya menghasilkan uang dalam penelitian ini yang dilakukan survivor skizofrenia di Kersamanah adalah membuat kerajinan tangan, makanan dan kue yang di 
jual ke warung di sekitar rumah dan membantu keuangan survivor itu sendiri. kerajinan tangan yang dimaksud adalah membuat mute dan bros. membuat makanan yang dimaksud adalah gendar, kerupuk, gorengan, manisan yang dijual di pom bensin dll.

\section{Berkebun dan Berternak}

Nurhayati (2014) dalam penelitiannya mengungkapkan bahwa modifikasi lingkungan berpengaruh besar terhadap proses penyembuhan pasien gangguan jiwa. terapi lingkungan berkebun berpengaruh terhadap peningkatan harga diri pasien di RSUD banyumas. $^{11}$ Sejalan dengan penelitian tersebut, penelitian ini menunjukan bahwa berkebun dan berternak merupakan upaya pasien dalam proses penyembuhan. Yang dimaksud berkebun adalah menanam padi, menanam singkong, menanam tanaman di sekitar rumah yang sewaktu waktu dapat digunakan sebagai bahan pangan keluarga survivor maupun dijual. Bertrenak yang dimaksud adalah memelihara ayam, itik, domba yang dapat dipergunakan keperluan sehari-hari maupun dijual ketika dibutuhkan.

\section{Bekerja dan berjualan}

Karmilawati (2011) mengungkapkan salah satu terapi penyembuhan pasien skizofrenia adalah terapi okupasi. Okupasi terapi adalah penyembuhan atau pemulihan terhadap individu dengan aktifitas-aktifitas yang sesuai dengan kebutuhan masing-masing. Terapi okupasi terbukti memiliki hubungan dengan tingkat kreatifitas pasien skizofrenia di RSJD Surakarta. $^{2}$ Dalam penelitian ini survivor melakukan upaya kreatifitas dengan bekerja dan berjualan. Bekerja yang dimaksud adalah sebagai pekerja bangunan, penjahit, buruh, berjualan di rumah, mengirimkan makanan ke warung-warung, dll.

\section{Mengurus anak dan membantu pekerjaan rumah}

Ibu rumah tangga merupakan salah satu bagian keluarga yang memegang peranan penting dalam keluarga. Ibu rumah tangga harus memiliki kesejahteraan psikologis sehingga fungsi keluarga dapat berjalan dengan baik. Ibu rumah tangga yang mengalami gangguan jiwa maupun yang memiliki suami gangguan jiwa harus berupaya menjalankan fungsinya sebagai tiang rumah tangga yang membentuk keluarga sakinah, sehat dan bahagia. ${ }^{12}$ Secara konsep memang merawat pasien gangguan jiwa memerlukan upaya yang berat, dan apabila tidak dapat mengatasinya maka akan mengalami depresi, apalagi pasien ibu rumah tangga yang juga mengalami gangguan jiwa tentu sangat berat dalam melakukan upaya kesembuhan. Ibu rumah tangga dalam menjalankan perannya mengurus anak, melakukan pekerjaan rumah seperti mencuci, memasak, mengepek, membereskan rumah dan apabial tidak dapat melakukan hal tersebut dapat hanya membantu pekerjaan rumah sesuai kemampuan survivor tersebut demi upaya kesembuhan.

\section{Berbincang-bincang dengan orang lain}

Selama ini banyak penelitian yang mengungkapkan bahwa bercakap-cakap efektif dalam mengontrol halusinasi pendengaran, misalnya penelitian Fresa dkk (2015) yang dilakukan di RSJ Dr. Amino Gondhohutomo Jawa Tengah. ${ }^{13}$ Dalam penelitian ini bercakapcakap dengan orang lain artinya tidak hanya mengontrol halusinasi, akan tetapi lebih kepada bersosialisasi, aktualisasi diri maupun mengalihkan permasalahan. Melalui bercakapcakap permasalahan yang selama ini membebani survivor menjadi lebih ringan, lebih terbuka fikiran maupun hanya untuk mengalihkan permasalahan yang saat itu dialami survivor. Berbincang-bincang yang dilakukan survivor tidak ada bedanya dengan percakapan individu sehat pada umumnya dan bagi mereka hal tersebut sangat membantu dalam proses penyembuhan. 


\section{Melakukan aktifitas didalam dan diluar rumah}

Melakukan aktifitas dalam penelitian ini artinya menolong orang lain yang membutuhkan, mendengarkan pengajian, mengikuti seminar umum dan menonton televisi. Seluruh aktifitas tersebut dilakukan atas inisiatif sendiri. Terapi aktifitas yang selama ini dilakukan pada pasien jiwa khususnya di rumah sakit bersifat himbauan dan diarahkan oleh perawat. Misalnya terapi aktifitas kelompok sosialisasi, stimulasi persepsi dll sesuai protap Rumah Sakit Jiwa atau yang berlaku.

\section{Kesimpulan}

Hampir semua survivor mengungkapkan bahwa mereka mandiri dalam melakukan aktifitasnya sehari-hari, melakukan rutinitas ibadah setiap hari, memiliki penghasilan untuk memenuhi kebutuhannya, makan sendiri, membersihkan rumah dll, akan tetapi mereka melakukan upaya kreatifitas dalam melakukan upaya kesembuhannya.

Dapat disimpulkan bahwa recovery bagi survivor skizofrenia merupakan sebuah perjalanan panjang dan perjuangan melawan penyakitnya, memahami perjalanan hidup yang mengubahnya menjadi survivor yang sembuh. Tantangan bagi petugas kesehatan untuk meningkatkan kembali kreatifitas survivor dalam upaya kesembuhannya.

\section{Saran}

Berdasarkan simpulan di atas, peneliti mengusulkan beberapa rekomendasi bagi pengembang pendidikan, peneliti lebih lanjut, dan pihak terkait sebagai berikut: (1) melakukan tindakan asuhan keperawatan yang tepat kepada survivor skizofrenia dengan memahami pengalaman survivor yang sembuh dari skizofrenia sehingga perawat bisa mengaplikasikan kreatifitas yang tepat sesuai dengan kemampuan survivor. ; (2) dapat menjadi masukan tentang proses yang dialami pasien skizofrenia yang sudah sembuh sehingga dapat dijadikan tambahan pengetahuan atau evidence based practice dalam proses belajar mengajar; (3) bagi peneliti lebih lanjut perlu kiranya dilakukan penelitian lebih lanjut untuk mempertahankan proses recovery di wilayah tersebut. Penelitian tersebut antara lain penelitian mengenai pengalaman survivor skizofrenia yang juga ibu rumah tangga dalam proses recovery .

Pengaruh terapi self help group (SHG) pada keluarga survivor skizofrenia, pengaruh family therapy bagi keluarga survivor skizofrenia, pengaruh assertive community treatment (ACT) pada masyarakat atau pasien yang menuju proses recovery, terapi supportif pada survivor skizofrenia dalam proses recovery.

\section{Daftar Pustaka}

1. Rahmawati, Lina. 2015. Pengalaman Hidup Survivor Skizofrenia dalam Proses Rceovery di Kersamanah Kabupaten Garut. Prosiding Unisba.

2. Karmilawati Pipit, (2011). Hubungan Kreatifitas Okupasi Terapi dengan Tingkat Kreatifitas pada pasien Skizofrenia di Rumah Sakit Jiwa daerah Surakarta. Skripsi Universitas Muhammadiyah Surakarta.

3. Norsyehan, dkk (2015). Terapi Melukis Terhadap Kognitif Pasien Skizofrenia di Rumah Sakit Jiwa Sambang Lihum. Jurnal. Banjarmasin : Poltekes Banjarmasin.

4. Riyadi, S \& Purwanto, P. (2009). Asuhan Keperawatan Jiwa. Jogjakarta : Graha Ilmu

5. Mainkar, Maya. (2014). Creativity and Mental Illness. Journal of Psychology and Behavioural Science. America. Vol.2 No.2, pp.137-146

6. Kaufman, S,B \& Paul Elliot S. (2014). Creativity and Schizofrenia Spectrum Disorders Across The Arts and Sciences. Article Psychology, Frontiers in Psychology, USA. 03 November 2014

7. Creswell JW. (2010). Research Design. 
Pendekatan Kualitatif, Kuantitatif dan Mixed. Edisi Ketiga. Jakarta: Pustaka Pelajar.

8. Streubert, H \& Carpenter, D (2007). Qualitative Research In Nursing : Advancing The Humanistic Imperative. $4^{\text {th }}$ Edition edn, Lipincott Williams \& Wilkins, Philadelphia

9. Lieberman JA. Effectiveness of antipsychotic drugs in patients with chronic schizophrenia. N Engl J Med. 2005; 353:1209-23.

10. Nursalim, Muhamad, (2016). Proses Pengembangan Kreatifitas Orang Dengan Skizofrenia (ODS) di Panti Hafara. Jogjakarta

11. Nurhayati Murniyati, (2014). Pengaruh terapi Lingkungan : Berkebun Terhadap Peningkatan Harga Diri Pasien Harga Diri rendah Di RSUD Banyumas. Skripsi Universitas Muhammadiyah Purwokerto

12. Hawari D. (2006). Managemen Stress. Cemas Dan Depresi. Jakarta : Fakultas Kedokteran Universitas Indonesia.

13. Oky Fresa, Dwi Heppy Rochmawati, M.Syamsul Arif SN. 2015. Efektifitas Terapi Individu Bercakap-cakap Dalam Meningkatkan Kemampuan Mengontrol Halusinasi Pada Pasien Halusinasi Pendengaran $d i \quad r s j \quad d r$ Amino Gondohutomo Provinsi Jawa Tengah. STIKES Telogorejo Semarang. Naskah Publikasi. 